\title{
Diffuse degassing of carbon dioxide on the NW sector of Colli Albani volcanic complex (Rome, Italy)
}

\author{
M.L. Carapezza \\ Istituto Nazionale di Geofisica e Vulcanologia, Sezione Roma 1, Rome, Italy \\ F.R. Roscioni, L. Tarchini \\ Dipartimento di Scienze Geologiche, Università ROMA TRE, Rome, Italy
}

\begin{abstract}
CO}_{2}$ soil flux surveys carried out at cava dei Selci on the Colli Albani volcano (28 seasonal surveys since the year 2000), have shown a significant variation of $\mathrm{CO}_{2}$ diffuse release, with a marked decrease, from 25 to 4 tons/day, from May 2000 to August 2004, followed by a new increase. In the same time $\mathrm{CO}_{2}$ flux halved at S. Maria delle Mole (16.8 tons/day in 2000 and 8.3 tons/day in 2006). Also the total quantity of $\mathrm{CO}_{2}$ dissolved in the deep waters of the Albano crater lake decreased by one order in the period 1997-2006. The high $\mathrm{CO}_{2}$ flux values could represent the "tail" of a strong degassing episode recorded at Colli Albani in 1995 and related to local earthquakes. The following decrease of $\mathrm{CO}_{2}$ release could reflect a permeability decrease caused by hydrothermal calcite precipitation favoured by $\mathrm{P}_{\mathrm{CO} 2}$ reduction in the deep source
\end{abstract}

\section{INTRODUCTION}

The Alban Hills volcano, near Rome, belongs to the Quaternary silica-undersaturated high-potassic Roman Comagmatic Province. Recent studies have shown that the volcano is not extinct but has to be considered in a quiescent state, as evidence has been found of Holocene lahars generated by Lake Albano water overflows until Roman times (Funiciello et al. 2002, 2003). The Alban Hills volcano is also the site of huge degassing (mostly of $\mathrm{CO}_{2}$ with minor $\mathrm{H}_{2} \mathrm{~S}$ ). These zones are generally located on faults cutting structural highs of the buried carbonate basement (Fig. 1), emit dozen of tons/day of $\mathrm{CO}_{2}$ and have locally created a serious gas hazard to people and animals (Carapezza et al. 2003, 2005a, 2006b). Several accidental gas blowouts also occurred from shallow water or geothermal wells creating a huge gas hazard (see Fig. 1) Groundwaters have high dissolved $\mathrm{CO}_{2}$ content (Chiodini \& Frondini 2001; Pizzino et al. 2002) indicating that there is a wide sector of Colli Albani interested by gas upraise from depth. Moreover, gas emissions occurs in many places over the structural high, where the superficial impermeable cover is removed by excavations, even only a few meters deep (quarries, house cellars, roads). This is the origin of Cava dei Selci gas manifestation (Carapezza et al. 2003). Similar is the case of the Solforata di Pomezia on the South western flank of the volcano, where gas emission occurs from an old mine excavation (Carapezza et al. 2005a). A CO $\mathrm{CO}_{2}$ input is also found on the bottom of Lake Albano, the most recent volcanic centre which is a crater lake $167 \mathrm{~m}$ depth (Cioni et al. 2003; Carapezza et al. 2005b and 2006a; Anzidei et al. 2007). In addition recent seismological and geodetic data have shown that Colli Albani volcano is affected by periodic seismic swarms and by an ongoing uplift (Amato \& Chiarabba 1995; Chiarabba et al. 1994 and 1997; Anzidei et al. 1998). During seismic swarms a strong increase in the degassing has been noticed (Quattrocchi \& Calcara 1998).

Since the year 2000 a study on the gas hazard of Colli Albani region has been carried out. Areas affected by anomalous gas release have been

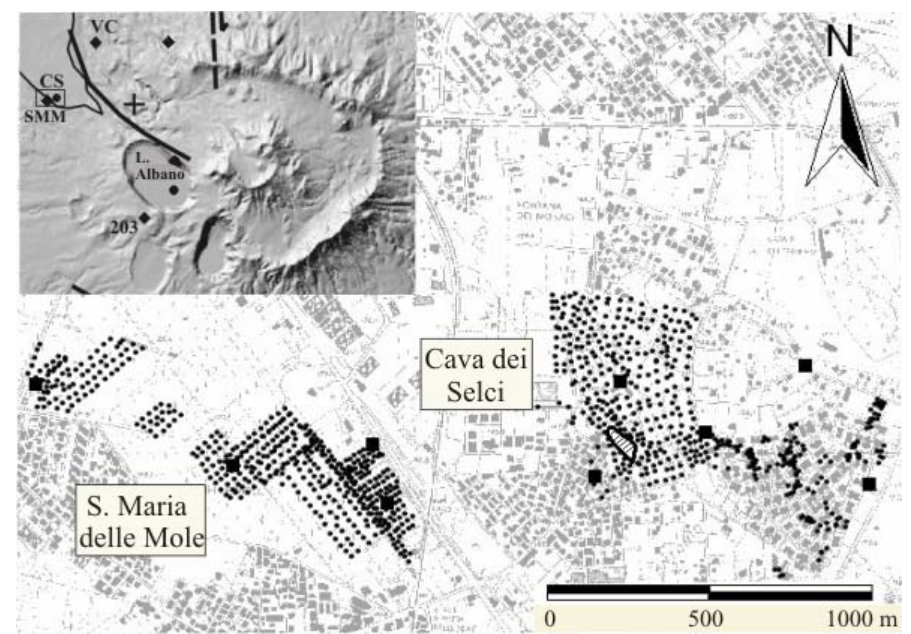


investigated to quantify the diffuse $\mathrm{CO}_{2}$ flux. The main emissive sites (i.e. Cava dei Selci, S. Maria delle Mole, Solforata di Pomezia, Albano Lake) have been systematically surveyed to monitor the gas emission (Carapezza et al. 2003, 2005a, b, 2006a, b). Here we present new data collected in the 2005-2006 period and discuss the possible meaning of some recorded time variations in gas release.

Figure 1. Map of the investigated area. Dots: $\mathrm{CO}_{2}$ flux measuring points; triangles: water wells affected by gas blowout. Insert on the left: DEM of the Alban Hills volcanic district. +1: Ciampino structural high; stroked line: main strikeslip faults; dots: gas manifestation sites (CS=Cava dei Selci, VC=Valle Cupella, SMM=S. Maria delle Mole, 203= S. Palomba); diamonds: wells

\section{THE GAS EMISSION SITES}

The main investigated area is indicated in Figure 1. Here more than $1000 \mathrm{CO}_{2}$ flux measures (dots in Fig. 1) have been carried out using the accumulation chamber method (Chiodini et al. 1998). Data were treated by lognormal probability plots as proposed by Sinclair (1974) and finally flux maps were elaborated by Kriging.

\subsection{Cava dei Selci}

Known since many years, it has been studied by Giggenbach (1998), Chiodini \& Frondini (2001), Carapezza et al. (2003 and 2005a). The new survey has been carried out in July-August 2005 around the main gas emission zone with 436 measures over a surface of 223,503 $\mathrm{m}^{2}$ (Fig. 2). The total diffuse $\mathrm{CO}_{2}$ flux, obtained by summing the gas release from all areas where average flux exceeded the background threshold (estimated to $35 \mathrm{~g} / \mathrm{m}^{2}$ day), has been estimated to 25 tons/day (from a total anomalous surface of $89,554 \mathrm{~m}^{2}$, about $1 / 3$ of the investigated area). From Figure 2 we can recognize three anomalous zones that are preferentially NW-SE aligned as the underlying structural high. The first one is near to the gas manifestation, on the SW sector, unfortunately in the mostly urbanized area. This is the largest anomalous area with a surface of $52,000 \mathrm{~m}^{2}$ and a $\mathrm{CO}_{2}$ flux of 18,6 tons/day. The second anomaly is found to the North of Cava dei Selci manifestation. It is centred on a dry gas emitting old water well (note its typical circular shape) and emits 2.13 tons/day from $3700 \mathrm{~m}^{2}$. The third anomaly is found in the NW sector. It is weaker than the others, with a total $\mathrm{CO}_{2}$ flux of 1.65 tons/day from $25,500 \mathrm{~m}^{2}$.

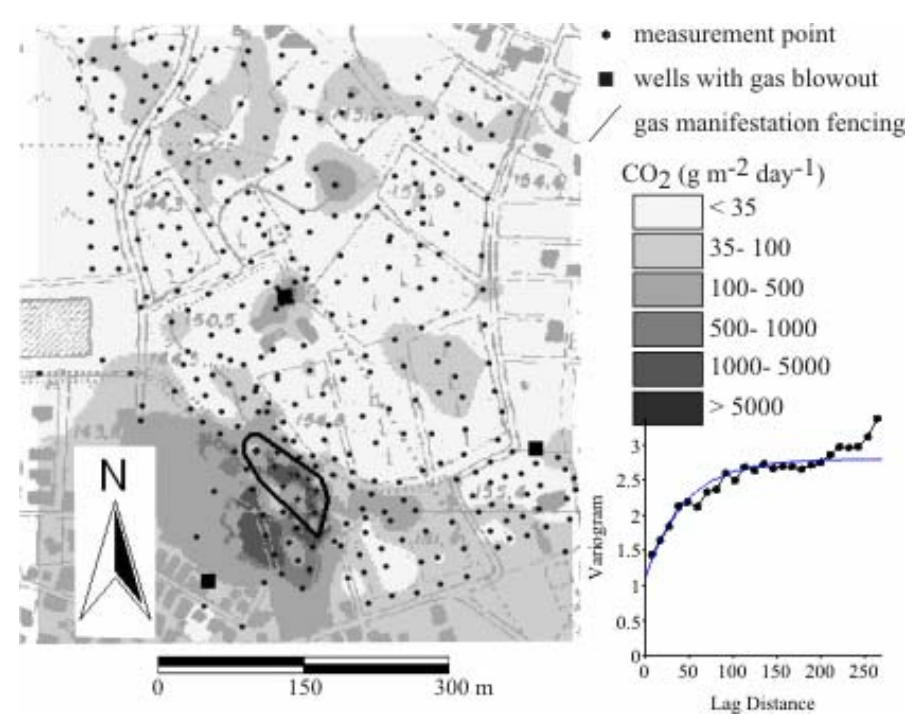

Figure 2. Map of the $\mathrm{CO}_{2}$ flux of the Cava dei Selci site.

\subsection{Variations with time of the $\mathrm{CO}_{2}$ flux from Cava dei Selci manifestation.}

In May 2000, a grid of 114 fixed points has been installed at Cava dei Selci, covering the main gas emission site of $6360 \mathrm{~m}^{2}$. Since then, 28 flux surveys have been carried out with a seasonal frequence. The results of the last 8 surveys are firstly presented in this work. The variation with time of the total $\mathrm{CO}_{2}$ flux, from May 2000 to October 2006, is reported in Figure 3. The highest values were measured in May 2000 (24.6 tons/day) and again in December of the same year (20.8 tons/day). Then a decreasing trend is observed, followed by low and nearly constant values recorded from March 2003 to August 2004 ( 4 tons/day). In fall 2004 a new increasing trend started, leading in 2006 to a mean value of 13 tons/day. From Figure 3 we can also observe a seasonal trend with minimum values in summer (see Carapezza et al. 2003 and 2005a for an explanation).

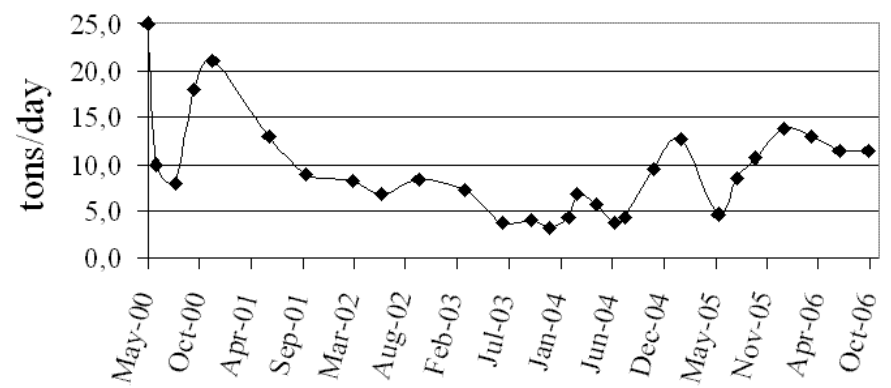

Figure 3. Variation with time of the total diffuse $\mathrm{CO}_{2}$ flux from the Cava dei Selci fixed grid.

\subsection{S. Maria delle Mole}

This zone is located $800 \mathrm{~m}$ SW of Cava dei Selci, on the same buried structural high. Four accidental gas emissions from shallow boreholes have occurred in this area. In the year 2000 Carapezza et al. 
(2005a) carried out a first survey (185 measuring points on 132,000 $\mathrm{m}^{2}$ ) and estimated a total diffuse $\mathrm{CO}_{2}$ flux of 18 tons/day most of which (16.8 tons/day) from only 5.4 hectares. In 2006 a wider zone of 22.7 hectares has been investigated by 474 measures on a regular grid (Fig. 4). We found flux values up to $8700 \mathrm{~g} / \mathrm{m}^{2}$ day with a mean value of 139 $\mathrm{g} / \mathrm{m}^{2}$ day, much lower than that found in the previous survey (588 $\mathrm{g} / \mathrm{m}^{2}$ day). The total diffuse $\mathrm{CO}_{2}$ flux is 12.4 tons/day from a surface of 9 hectares. A flux of only 8.3 tons/day was estimated in 2006 from the same anomalous surface of 5.4 hectares where in 2000 the $\mathrm{CO}_{2}$ flux was more than the double. Both surveys display the same geometry of the gas anomaly, that is aligned NW-SE coinciding with the direction of the faults bordering the buried carbonate horst. The area of maximum degassing is in the proximity of two water wells where gas blowout occurred in the recent past.

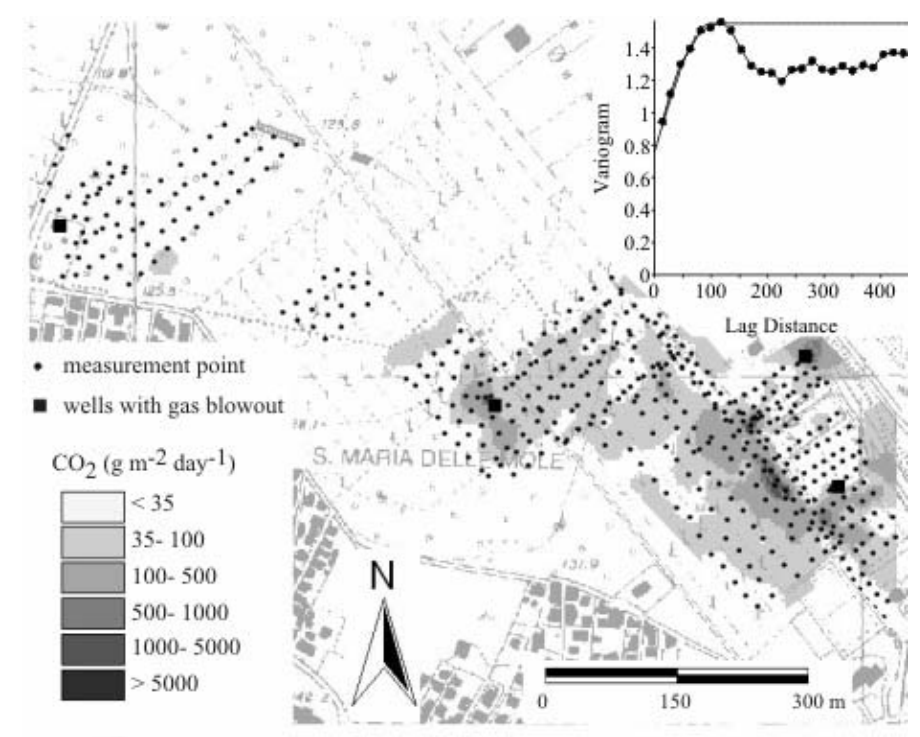

Figure 4. Map of the $\mathrm{CO}_{2}$ flux of S. Maria delle Mole.

\section{GAS COMPOSITION AND ORIGIN}

Both Cava dei Selci and S. Maria delle Mole gases have been sampled and analyzed and data compared with pre-existing gas analyses of the Colli Albani region. The main component is $\mathrm{CO}_{2}(>90$ vol.\%) followed by $\mathrm{H}_{2} \mathrm{~S}, \mathrm{~N}_{2}$ and $\mathrm{CH}_{4}$. In Figure 5, the gases of the main Colli Albani manifestations are plotted in the $\mathrm{N}_{2}-\mathrm{He}-\mathrm{Ar}$ triangle. The sample position and the ${ }^{3} \mathrm{He} /{ }^{4} \mathrm{He}$ values, up to $1.9 \mathrm{R} / \mathrm{Ra}$

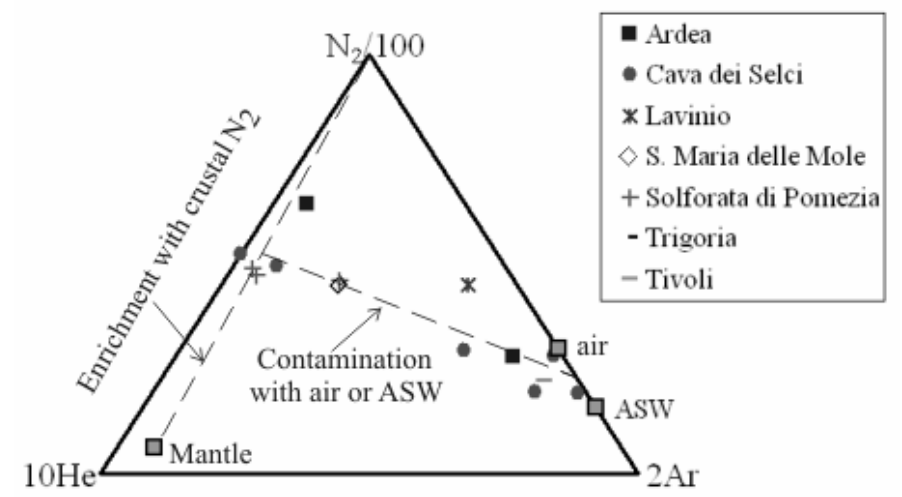

(Carapezza \& Tarchini, 2007), suggest a common origin by progressive contamination of a deep component (a mantle gas enriched in crustal $\mathrm{N}_{2}$ ) with air, or more likely with air saturated groundwater (ASW).

Figure 5. $\mathrm{N}_{2}-\mathrm{He}-\mathrm{Ar}$ triangle with Colli Albani gases.

\section{DISCUSSION AND CONCLUSIONS}

The new $\mathrm{CO}_{2}$ soil flux and chemical data collected in 2005-2006 confirm that the quiescent Colli Albani volcano, and particularly its Western sector, is a site of very huge degassing of endogenous deep originated (mantle or magmatic) $\mathrm{CO}_{2}$. The gas rising from depth accumulated in traps at the top of the structural highs of the main carbonate reservoir confined beneath an impervious cover. From here it raises towards the surface along leaking structures, as the deep reaching faults bordering the carbonate horst, as it is indicated by the widespread occurrence of $\mathrm{CO}_{2}$ anomalous releasing zones above the horst and by their preferential elongation on the same NW-SE direction of the tectonic structure. $\mathrm{CO}_{2}$ rising from the carbonates encounters and partly dissolves into shallower aquifers, sometimes up to oversaturation.

The repetition of $\mathrm{CO}_{2}$ flux surveys in the same zones and with the same measuring point distribution, permitted to ascertain a systematic strong decrease of $\mathrm{CO}_{2}$ emission at Cava dei Selci and S. Maria delle Mole from the year 2000 to at least the end of 2004. It is possible that the high $\mathrm{CO}_{2}$ fluxes measured in 2000 represent the "tail" of an anomalous release, not quantified, reported in 1995 at Cava dei Selci and in other zones of Colli Albani (Chiodini \& Frondini 2001) and put in relation with two seismic events occurred in proximal areas. Anomalous gas emissions in relation to earthquakes have been reported at Colli Albani by numerous, recent and antique, chronicles (Funiciello et al. 2002). The decrease of $\mathrm{CO}_{2}$ flux observed since 2000 could be due to the decrease of gas overpressure in the deepest source produced by the strong gas release caused by the seismic fracturation. Or it could have been produced, perhaps more likely, by a progressive partial sealing of the deep fracture by deposition of calcite induced by a decrease of $\mathrm{P}_{\mathrm{CO} 2}$ at depth. In this latter case, the new $\mathrm{CO}_{2}$ flux increase recorded at Cava dei Selci since August 2004 could reflect a $\mathrm{P}_{\mathrm{CO} 2}$ increase in the reservoir, caused by the partial sealing of the cover, which produces a flux increase along the main, though reduced, gas leaking structures. It is interesting to observe that in the same time span (1997-2006) a marked reduction of one order of magnitude (4187 against 465 tons) has been 
observed in the quantity of $\mathrm{CO}_{2}$ dissolved in the deep waters of Lake Albano. This reduction could have been at least partly produced by lake-rollover phenomena (Anzidei at al 2007) but it could also reflect a similar process of partial sealing of the gas leaking structures connecting the gas reservoir with the lake bottom.

We recall that an analogous process characterized by two contrasting phenomena as a $\mathrm{CO}_{2}$ increase caused by earthquake-induced permeability increase and a flux reduction caused by hydrothermal selfsealing of the fractures, was suggested by Granieri et al. (2006) to explain the strong increase recorded during seismic crises at La Fossa of Vulcano. If this is the process governing the variation of $\mathrm{CO}_{2}$ flux in volcanic and geothermal areas, the seismicity causing its increase can have either an external cause, for instance the action of a strong regional earthquake on the local stress field, or be generated by the reservoir gas overpressure itself, reached after a prolonged accumulation period related to the reduced permeability of the cover.

\section{REFERENCES}

Amato, A., Chiarabba, C., Cocco, M., Di Bona, M. \& Selvaggi, G. 1994. The 1989-1990 seismic swarm in the Alban Hills volcanic area, central Italy. J. Volcanol. Geotherm. Res. 61, 225-237.

Amato, A. \& Chiarabba, C. 1995. Recent uplift of the Alban Hills Volcano (Italy): evidence for magmatic inflation? Geophys. Res. Lett. 22, 1985-1988.

Anzidei, M., Baldi, P., Casula, G., Galvani, A. Riguzzi, F \& Zanutta, A. 1998. Evidence of active crustal deformation of the Colli Albani volcanic area (central Italy) by GPS surveys. J. Volcanol. Geotherm. Res. 80, 55-65.

Carapezza, M. L., Badalamenti, B., Cavarra, L. \& Scalzo, A. 2003. Gas hazard assessment in a densely inhabited area of Colli Albani Volcano (Cava dei Selci, Roma). J. Volcanol. Geotherm. Res. 123, 81-94.

Carapezza, M. L., Barberi, F., Tarchini, L., Cavarra, L. \& Granieri, D. 2005a. Le emissioni gassose dell'area vulcanica dei Colli Albani. In: Nuovi dati sull'attività recente del cratere del lago Albano e sul degassamento dei Colli Albani. Atti Acc. Naz. Lincei 218, 229-242.

Carapezza, M. L., Cioni, R., Guidi, M., Lelli, M. \& Tarchini, L. 2005b. Geochimica delle acque dei laghi Albano e Nemi. In: Nuovi dati sull'attività recente del cratere del lago Albano e sul degassamento dei Colli Albani. Atti Acc. Naz. Lincei 218, 243-248.

Carapezza, M. L., Lelli, M. \& Tarchini, L. 2006a. Geochemistry of the Albano and Nemi craters lakes in the volcanic district of Alban Hills (Rome, Italy). J. Volcanol. Geotherm. Res. Spec. Vol. "Volcanic Lakes".

Carapezza, M. L. \& Tarchini, L. 2006b. Magmatic degassing of the Alban Hills volcano (Rome, Italy): geochemical evidence from accidental gas emission from shallow pressurized aquifers. Submitted to J. Volcanol. Geotherm. Res.

Chiarabba, C., Amato, A. \& Delaney, P. T. 1997. Crustal structure, evolution, and volcanic unrest of the Alban Hills, Central Italy. Bull. Volcanol. 59, 161-170.
Chiodini, G. \& Frondini, F. 2001. Carbon dioxide degassing from the Alban Hills volcanic region, Central Italy. Chem. Geol. 177, 67-83.

Cioni, R., Guidi, M., Raco, B., Marini, L. \& Gambardella, B. 2003. Water chemistry of Lake Albano (Italy). J. Volcanol. Geotherm. Res. 120, 179-195.

Funiciello, R., Giordano, G. \& De Rita, D. 2003. The Albano maar lake (Colli Albani Volcano, Italy): recent volcanic activity and evidence of pre-Roman Age catastrophic lahar events. J. Volcanol. Geotherm. Res. 123, 43-61.

Giggenbach, W.F., Minissale, A.A. \& Scandiffio, G. 1998. Isotopic and chemical assessment of geothermal potential of the Colli Albani area, Latium, Italy. Appl. Geochem. 3, 475-486.

Quattrocchi, F. \& Calcara, M. 1998. Test-sites for earthquake prediction experiments within the Colli Albani region. Phys. Chem. Earth, 23, 915-920.

Salvi, S., Atzori, S., Tolomei, C., Allievi, J., Ferretti, A., Rocca, F., Prati, C., Stramondo, S. \& Feuillet, N. 2004. Inflation rate of the Colli Albani volcanic complex retrieved by the permanent scatterers SAR interferometry technique. Geophys. Res. Lett. 31, 12 doi: 10.1029/2004GL020253.

Sinclair, A. J. 1974. Selection of threshold values in geochemical data using probability graphs. J. Geochem. Expl. 3, 129 -149.

Tuccimei, P., Giordano, G. \& Tedeschi, M. 2006. $\mathrm{CO}_{2}$ release variations during the last 2000 years at the Colli Albani volcano (Roma, Italy) from speleothems studies. Earth Planet. Sci. Lett. 243, 449-462. 